\title{
Peranan Konselor dalam Penerapan dan Pemupukan Nilai-Nilai Murni Melalui Rogram Konseling terhadap Remaja di Sekolah: Satu Wadah Terpadu antara Guru dan Kounselor
}

\author{
Nova Erlina \\ Dosen Fakultas Tarbiyah dan Keguruan, IAIN Raden Intan Lampung \\ Diterima: April 2014. Disetujui: Mei 2014. Dipublikasikan: Juni 2014
}

\begin{abstract}
Abstrak: Penelitian ini bertujuan untuk meninjau peranan konseling ke arah pembangunan insan yang qamil. Peneltiian ini akan meninjau dan memahami persfektif kaunseling barat terhadap fungsi penelitian manusia di muka bumi berdasarkan teori freud dan rogrs. Persoalannya mengapa kehidupan manusia di muka bumi ini menimbulkan masalah khususnya dari aspek spiritual walau pun telah kerap kali menerima terapi konseling. Penyakit yang berkait dengan kekacauan mental seperti new rosis, Ketidak stabilan emosi, setres, gangguan pikiran dan sebangainya merupakan bukti seseorang itu memerlukan bantuan kaunseling. Pembentukan model yang berteraskan pembagunan insan yang menyeluruh ini di harapkan dapat di praktekkan untuk merawat klien yang menghadapi masalah pribadi, keluarga dari masyarakat. Model ini di harapkan menjadi satu mekanisme beladiri klien untuk menangani setiap permasalahan bukan saja dari aspek spiritual, bahkan membentuk manusia yang sehat, motipasi, mempunyai kenyakinan diri dan bersedia menghadapi semua permasalahan dan tantangan dalamkpehidupan seseorang manusia itu pada masa akanyany dating.
\end{abstract}

Kata Kunci: program konselor, program konseling

\section{Pendahuluan}

Remaja merupakan komponen penduduk yang penting dalam sesebuah Negara. Di samping merupakan pelapis yang akan menggantikan golongan dewasa, merupakan juga bakal mengambil alih semua urusan negara dari segi politik, Sosial, ekonomi dan pertahanan keselamatan Negara. Sebagaimna mereka menjadi pemimpin Negara, bekerja dalam bimbingan professional dan ada juga menjadi tenaga kerja yang mahir didalam dan diluar Negara. Oleh sebab kepentingan ini, maka golongan ini tidak boleh dipinggirkan. Memang benar, disebabkan faktor biologi dan usia mereka diantara 12 hingga 21 tahun belum matang (Ibrahim, 2001). Justru, golongan remaja ini perlu diberi perhatian supaya perkembangan mereka dari segi fisik, rohani, emosi dan intelektual dapat berkembang denganseimbang sekaligus dapat memberi sumbangan yang positif terhadap kemajuan Negara.

Remaja dapat kategorikan sebagai anak muda yang berumur 12 hingga 21 tahun, mengalami proses perkembangan menjadi dewasa, mulai matang, bisa berfikir sendiri membedakan nilai yang yang baik atau buruk dan mengalami proses pemantapan fisik, intelektual, rohani dan emosi. Menurutnya lagi, remaja juga bisa dianggap sebagai golongan yang 'akal baligh' yakni sudah cukup umur untuk menikah apalagi timbul cinta yang berahi remaja yang disenangginya (Ibrahim, 2001).

Masalah sosial yang melanda masyarakat bukan saja terkena kepada orang dewasa tetapi melibatkan remaja. Di kota- kota besar bahkan sangat cepat perkembangannya terjadi. Masalah ini lebih ketara oleh Penulis karena masalah remaja bertambah seiring dengan pesatnya perkembangan industrialisasi dan urbanisasi. Masalah besar yang di hadapi remaja adalah masalah tingkah laku, yaitu perbuatan yang menyimpang dari budaya biasa dalam masyarakat. Salah tinggah laku remaja dapat dikategorikan menjadi dua jenis yaitu salah tingkah laku biasa dan salah tingkah laku yang luar biasa.

Tingkah laku biasa: tingkah laku biasa ialah tingkah laku menyimpang dari yang biasa terdpat dalam masyarakat yang dilakukan oleh remaja normal akibat dari tekanan sosial. Hal ini terjadi karena tiga sebab: 
1. Keadaan diri yang tidak mendapat latihan dan pengawalan disiplin sehingga tidak sanggup mengikuti norma biasa. Contohnya ialah hubungan seks bebas dan homoseksual.

2. Keadaan keluarga broken-home dan tidak harmonis yang menyebabkan timbulnya rasa kecewa. Contoh tingkah laku jenis ini ialah lari dari rumah. pergaulan bebas, mencuri dan penyalahgunaan narkoba.

3. Keadaan lingkuangan sekitar yang memancing keinginan diri untuk mengikuti gaya dan meniru suatu perkumpulan. Contoh kongkrit ialah merokok, berkelahi antara geng preman yang satu dengan geng preman yang lainnya.

Tingkah laku luarbiasa: Seseorang yang melakukan salahlaku luarbiasa sebenarnya menderita sakit jiwa bersumber dari tekanan sosial yang hebat yang tidak dapat diatasinya. Tingkah laku kategori ini terbagi kepada tiga jenis:

1. Tingkah laku neurotic, yaitu salahlaku yang timbul akibat daripada penderitaan karena gangguan mental yang menyebabkan pengidapnya senantiasa merasa takut, bingung, bersalah dan berdosa. Remaja neurotic memilki rasa rendah diri yang mendalam dan suka mengasingkan diri. Keadaan ini bisa meletus menjadi hysteria.

2. Tingkah laku psikopatik, yaitu tingkah laku yang terjadi akibat dari pada ketakutan mental sehingga tidak dapat menginterakrasikan dirinya. Pengidapnya menpunyai sikap yang selalu berkonflik dengan norma- norma sosial, sangat egoistic, panatik, kasar dan suka menyakiti orang lain. Remaja pisikopatik akan marasa puas jika dapat menggangu, mencetuskan perkelahian dan melihat orang lain menderita.

3. Tingkah laku cacat normal, yaitu tingkah laku disebabkan sakit mental atau sakit jiwa sehingga pengidapnya tidak mampu mengenal, memahami dan mengendalikan tingkahlakunya. Pengidapnya tidak memiliki harga diri atau sikapnya sangat dingin. Dia selalu melakukan tingkah laku anti sosial. Remaja yang melakukan tingkah laku ini biasanya tidak siuman.

Justru itu, satu wadah tersepadu dia antara peranan dan tanggung jawab konselor di bantu oleh guru sekolah adalah perlu bagi menjamin disiplin dan tingkahlaku golongan remaja ini terpelihara. Oleh karena itu, penyemaian nilai-nilai murni terhadap golongan remaja adalah perlu mebentuk remaja yang mempunyai keseimbangan dari segi intelegtual, rohaniah, fisikal dan

perdaban sesuai dengan Islam.

Penerapan nilai nilai murni melalui pendidikan adalah untuk melahirkan insan yang baik dan berakhlak mulia bertujuan untuk (Zahid, 2004): (1) Menanam, kesadaran, femahaman, kenyakinan, dan kesyukuran dikalangan pelajar, (2) Menanam semangat cinta dan nilai nilai suci, (3) menghormati keburukan dan membenci keburukan (4) membentuk sikap positif dan berguna untuk agama, bangsa dan bertanggung jawab (5) menghapus sikap negative dalam kehidupan dan sewaktu menjalankan tanggung jawab. (6) menjalankan amanah dengan dedikasi (7) meningkatkan hasil produktivitas berusaha mencapai kesuksesan.

\section{Metode Penelitian}

Metode penelitian ini dilakukan dengan deskriptif kualitatif dalam tulisan ini peneliti menggunakan studi pustaka atau menggali data dari library research untuk memperkaya khasanah keilmuan bimbingan dan konseling.

\section{Hasil Dan Pembahasan}

Remaja perlu sadar tentang tujuan hidup dimuka bumi ini. kehidupan dimuka bumi ini ialah sebagai khalifah. peranan khalifah yaitu menjadi pemimpin dimuka bumi ini untuk mentadbir seluruh alam semesta (Ibrahim, 2001). Kesadaran konsep ini jelas sebagaiman firman Allah S.W.T. yang dimaksud: "ingatlah ketika tuhanmu berfirman kepada malaikat "sesungguhnya aku hendak menjadi seorang kalifah dimuka bumi" (al-Baqarah:30) Remaja perlu ditekankan dengan konsep dan tujuan kehidupannya dimuka bumi ini supaya mereka sadar akan tanggung 
jawab mereka. Asas ini menekankan bahawa manusia mempunyai tujuan hidup yang perlu disesuaikan dengan segala kegiatan dan keperluannya. kepada manusia diingatkan bahawa hidup ini dari allah dan akan kembali kepada allah. oleh karena itu, hendaknya berjalanlah selari dengan tujuan allah yang dijadikannya. firman allah yang artinya: "dan tidaklah aku jadikan jin dan manusia selain untuk mengabdikan diri (taat) kepadaku". (surat al-zariah:56).

Mengabdikan diri kepada allah dengan arti hidup sesuai dengan kehendaknya. segala gerak gerik kerja yang dilakukan oleh remaja yang dalam kehidupan sesui dengan petunjuk dan aturan Allah baik dalm kehidupan individu seperti makan, melakukan aktivitas permainan dengan sebaiknya. semuanya mempunyai tujuan yakni hanya kepada Allah S.W.T. semata mata (Johari, 1994).

Disamping itu, kaunselor juga seharusnya menanam konsep diri yang positif terhadap diri remaja. konsep kendiri ini adalah mencakup aspek jasmani dan psikologi. Seseorang yang senantiasa mendapat perhatian, menggalakkan usaha usahanya dan memujinya akan mendorong orang itu membentuk dirinya kearah konsep diri yang positif adalah dipercayai, golongan remaja dari psikologi dan emosinya merupakan golongan yang senantiasa berubah dari segi emosi, agresif, bertingkah laku sukar dijangka dan terka terhadap masalah dan perubahan disekeliling (Ibrahim, 2001) justru, remaja adalah individu yang lain. mempunyai kepercayaan, prinsip dan nilai dalam dirinya tersendiri. Mereka mempunyai hak dan keistemewaan dalam mengatakan pendapat pendapat tertentu dan berhak mendapat pendapat orang lain terhadap dirinya (Habibah \& Noran,

2002). Oleh itu, penerimaan orang yang penting dalam hidup remaja itu seperti ibu bapak. keluarga dan konselor mempunyai kesan yang bermakna diatas pembinaan konsep diri mereka. desekolah, segala tindak tanduk kawan-kawan dan guru guru boleh memberi kesan diatas keyakinan diri remaja harapannya, harga diri, sikap dan motivasi.

Penulis percaya remaja yang sering mendapat perhatian, diberi pujian dan dorongan akan mempunyai konsep diri dalam hidup khususnya dari segi tingkah laku mereka. Antara cirri- ciri tingkah laku yang diperhatikan oleh remaja yeng mempunyai konsep diri yang positif ialah berpuas hati dengan dirinya, pemarah, mudah berkawan, berpuas hati dengan pencapaiannya, tau menghargai sesuatu yang dilakukan dan bersedia untuk memuji orang lain.

Penulis berpandangan remaja yang telah dapat mengendalikan diri, mengetahui konsep diri, tau menghargai diri, mengetahui kekuatan dan kelemahan diri dan mengetahui tujuan hidup akan dapat menjalani kehidupan dengan sempurna. Yang mengatakan sifat sifat personality individu yang hatinya tenang dan damai dalam hidup ialah insan yang senantiasa bertaubat, takut kepada Allah, sabar, bersukur, ikhlas, tawakal, cinta kepada Allah, redha, qada, dan qadar Allah dan mengingati akan datang waktu ajalnya nanti (Ismail, 1998). Justru, lebih jelas peranan konselor ini adalah berusaha menanam dan memupuk usaha mengenal diri, mewujudkan konsep diri terhadap remaja dan penting membentuk tujuan hidup remaja dalam setiap pogram motivasi. kita tidak tahu remaja masakini yang menjadi tiang harapam negara, hilang arah dan tujuan dalam hidup. Justeru mereka disadarkan, ditanamkan dan dibekalkan dengan suatu iltizan dan semangat jati diri yng utuh dan kekal melalui penerapan nilai nilai yang luhur dalam diri mereka (Noordin, 1993) Idealnya hal ini dimasukkan kedalam kurikulum sekolahuntuk memastikan semua nilai-nilai murni itu diserap secara langsung atau tidak langsung oleh pelajar dengan hati yang ikhlas, jujur, tulus dan terbuka.

Program ceramah meliputi ceramah teknik kemahiran belajar yang perlu dianjurkan oleh konselor untuk meningkatkan prestasi akademik seperti ceramah teknik bimbingan belajar untuk ujian UPRS, PMR, SPM, STPM dan sebagainya. hal ini tercantum dalam program kementrian pendidikan Malaysia yang menjelaskan bahawa peranan guru konseling dan aktivitas pemilihan mata pelajaran elektif untuk ujian seperti PMR, SPM dan STPM (Malaysia, 2002). 
Di Malaysia banyak pusat bimbingan belajar cemerlang meminta dan motivasi ujian telah didirikan sesuai dengan kesadaran kedua orang tua, para pendidik terhadap pentingnya semangat dan motivasi kepada anak-anak mereka. Diantaranya seperti didirikanya excel training yang didirikan oleh pakar motivassi yaitu datuk Dr. Fadzillah kamsah bersama rekan rekannya bertujuan untuk memberi kesadaran dalam pelajaran dan berusaha meningkatkan motivasai baik individu maupun kelompok. Bantuan diskusi bukan saja meliputi golongan pelajar sekolah dan IPT. bahkan melibatkan para pekerja disektor umum, pekerja swasta, golongan korprat dan juga professional.

Program ketrampilan remaja yang dianjurkan sudah tentu dapat membentuk dan menimbulkan kesadaran dan meningkatkan motivasi pelajar untuk menghadapi ujian yang bakal dihadapi. penerapan nilai yang dimaksudkan disini ialah nilai kejujuran, kenyakinan diri, bersungguh sungguh, keberanian dan keikhlasan dalam diri terbentuk tanpa disadari. walaupun tiada pengawas ujian, baginya, konsep kejujuran semasa menjawab kertas ujian telah didalam dirinya (Ghayani, 1996). Peranan nilai nilai secra tidak langsung kedalam teknik kemahiran belajar diharapkan dapat menghapuskan niat peserta didik yang hadir kesekolah semata mata untuk lulus ujian semata mata. situasi ini jelas sebagaiman menurut (Noordin, Pendidikan dan Wawasan

2020, 1992) yang menyatakan bimbingan terhadap pelajar lewat tahun 80an yang menjadikan ujian yang dihayati merupakan medan pengukuran kesuksesan masa depan dan sebaliknya kurang menghayati nilai dalam sistem persekolahan itu sendiri. maka disinilah peranan konselor bersama sama dengan guru penerapan dan membina nilai nilai dikalangan peserta didik.

Peranan guru disekolah dalam usaha memastikan para peserta didiknya tidak dalam penggunaan narkoba haruslah berusaha menyusun dan membentuk program pencegahan tra narkoba, rokok dan alcohol. antaranya adalah usaha menggalakan para peserta didik sekolah terlibat aktif dalam persatuan peserta didik ataupun kegiatan extra kurikuler yang lainnya. Kaunselor sekolah perlu mengadakan program dan aktivitas-aktivitas berikut yang dirasakan sesuai untuk menggalakkan remaja sekolah mempunyai kesedaran terhadap bahaya narkoba. Antaranya seminar bahaya narkoba, pelatihan membina ketahanan diri, program intelek bimbingan rohani, sekolah anak didik, skin lencana anti dadah (SLAD), kursusnya pendidikan pencegahan dadah PIBG/Guru, program pembimbingan rakan sebaya dan program lima minit.

Menurut sumber agensi narkoba kebangsaan (2001) dibawah unit kurikulum, kementrian pendidikan malaysia. unit bimbingan dan kaunseling telah didirikan dengan tujuan untuk: (1) memastikan penyertaan peserta didik dalam aktivitas ko- kurikuler (pesera didik diwajibkan mengambilkan dua dari pada tiga bidang: olah raga, permainan-permainan dan kesenian) (2) menghadiri selama pertandingan, karangan ilmiah, poster dan logo anjuran kementrian dengan kerjasama agensi agensi luar dan pihak swasta (3) menggiatkan kelompok bimbingan dan kauseling disekolah dan di perguruan tinggi (4) mendirikan organisasi anti narkoba disekolah dan diperguruan tinggi kegiatan- kegiatan khusus mencegah narkoba dikalangan peserta didik yang dikelola oleh pihak sekolah melalui unit bimbingan dan kaunseling dengan kerjasama dinas pendidikan daerah adalah seperti berikut: (5) organisasi kesuksesan diri: ini khusus untuk peserta didik bermasalah dengan narkoba. penekanan diberi terhadap nilai nilai murni keagamaan dan moral, disiplin diri, memahami potensin diri, berkomonikasi menyelesaikan masalah. (6) kursus kesadaran pesert didik: bertujuan menanamkan sikap membenci narkoba dan memahami akibat narkoba pada diri, keluarga, masyarakat, ekonomi Negara dan keagamaan. (7) Mengadakan kelompok peserta didik yang bisa menyebarkan pesan anti narkoba, menolong rekan sebaya, seterusnya aktif dalam aktivitas-aktivitas pencegahan narkoba.

Penerapan nilai nilai murni sebenarnya telah lama diterapkan kepada golongan remaja. sebagaimana telah dijelaskan usaha membasmi penggunaan narkoba bukan saja terletak 
dikalangan guru sekolah, kaunselor, orang tua, bahkan tetangga, masyakat umumnya. Orang tua misalnya, harus bikjak sana mendekati anak remaja mereka. mereka seharusnya mempunyai nilai untuk bersama dengan keluarga seperti meluangkan waktu bersama anak. memberikan didikan agama dan moral, memberikan pujian kepada mereka dan belaku adil dari segi layanan kepada mereka (Agensi narkoba kebangsaan 2001). maka jelaslah dengan adanya penerapan nilai nilai terhadap program pencegahan narkoba, rokok dan alcohol dapat menimbulkan kesedaran kefahaman dan sifat benci remaja terhadap gejala ketagihan narkoba, rokok, alcohol dan berbagai jenis bahan bahan ketagihan dianggap satu benda yang jijik dan berbahaya kepada mereka, tidak membawa sembarang faedah dan lebih diyakini lagi ialah bahan bahan ini merusakkan sistem tubuh sehingga membahayakan kesehatan diri mereka (Abdul Ghafar, 1998).

Menurut kementrian pendidikan (2002) peranan kaunselor di sekolah juga mencakupi penyediaan program bimbingan karir kepada peserta didikr. seorang konselor yang prihatin terhadap perkembangan karir peserta didik. seseorang kaunselor yang prihatiin terhadap perkembangan kerir peseta didik seharu93snya menfokuskan pada 5 langkah ber ikut yaitu: (1) kesadaran dan minat sukses (2) perencanaan kerir (3) perlaksanaan (penggunaan kosioner karir) (4) sumber impormasi dan pemilihan karir peserta didik (5) masa depan kerir peserta didik.

Ada 5 langkah yang perlu dipraktekkan oleh konselor untuk mendorong peserta didik dalam menentukan kerir mereka yaitu: (1) konselor perlu mengarahkan guru sekolah unruk mengenal pasti masalah karir dihadapi oleh peseta didik yang diajar mereka (2) konselor perlu melibatkan setiap guru perlu menyediakan daftari lengkap tentang pekerjaan yang khusus yang mempunyai hubungan dengan mata pelajaran yang diajarkan. (3) menyedikan bahan bahan tertulis dan alat panduan tentang pekerjaan (4) melibatkan guru guru dengan proyek hari berir, lewat pusat perniagaan dan perindustrian dengan melibatkan peserta didik. (5) melibatkan guru dalam penelitian yang sistematik bagi peserta didik disekolah baik yang sudah pekerjaan atau yang belum bekerja sama sekali.

Penerapan konselor disini ialah merupakan nilai nilai yang mendorong peserta didik memilih kerir yang mengutamakan nilai nilai luhur bukannya berasaskan pekerjaan yang termashur. falsafah pemilihan karir yang kungruen antara minat dan nilai ini telah dinyatakan oleh beberapa tokoh pekerjaan seperti Ann Roen dan Ginzberg dalam muhd Mansur yang menyatakan pentingnnya aspek nilai dalam pemilihan pekerjaan. justeru itu, jika seseorang pelajar itu memilih kerir kedokteran misalnya, dia menjadi seorang dokter yang mempunyai nilai disiplin yang tinggi, kejujuran, keikhlasan ingin menolong dan sebagainya. pendek kata, nilai meterialistik dipinggirkan kerana niat bekerja adalah untuk menolong bukannya mengutamakan kepentingan dan faedah diri (Abdullah, 2001).

Maka perlu konseling karir mengikut pendekatan dan panduan ajaran agama islam supaya kesan konseling tersebut tidak menjelaskan aqidah, syariah, akhlak umat islam sepanjang proses kaunseling tersebut, disamping memerlukan pahala. ini disebabkan jika proses konseling yang dilalui hanya konseling biasa kaunselor dirujuk merupakan kaunselor yang materialistic mungkin dapat membantu menyelesaikan masalah yang dihadapi tetapi diragukan akan memberikan kesan yang buruk di akhirat nanti (Ikhwan, 2002).

Bimbinag individu dan bimbingan kelompok yang sempurna antara konselor dengan klien adalah untuk membantu klien kearah mengenal diri, memahami diri, melihat kelemahan diri dan menggunakan seluruh potensi kearah kesempurnaan diri, setelah diri mendapat celik akal diri pada proses konseling itu (Rogers, 1961). Inpormasi dan proses konseling individu dan bimbingan kelompok itu sendiri mendorong konselor membantu klien secara jujur, ikhlas dan penerimaan tanpa syarat (Abdullah, 2001) dalam islam perbuatan menolong orang yang dalam kesusahan ada dinyatakan hadist. Abu Hurairah r.a meriwatkan bahawa Rasulullah SAW pernah bersabda yang bermaksud: "barang siapa yang melapangkan kesempitan didunia saudaranya yang islam, niscaya Allah akan melapangkan baginya kesempitan akhirat dan barang siapa yang merinagnkan seseorang yang berada dalam kesempitan, maka Allah akan 
meringankan keatasnya didunua dan akhirat. Allah membantu seorang hamba, selagi hamba itu membantu saudaranya yang islam."

Justeru itu, nilai-nilai positif seperti tolong menolong, keikhlasan, kejujuran, rasa simpati merupakan cirri ciri yang perlu ada pada seseorang kaunselor untuk menolong kliennya. nilai nilai ini dilihat lebih spesipik dalam pelaksanaan bimbingan kelompok itu sendiri memperlihatkan kepentingannya. misalnya pelaksanaan kaunseling kelompok banyak mempunyai nilai-nilai positif. seseorang kaunselor yang bijaksana tentu memainkan peran penting kerena kerja mewujudkan perkongsian pengalaman, ide dan permasalah bagi mengurangi permasalahan anggota dalam kelompok sehingga mewujudkan rasa simpati rekan rekan dalam kelompok terhadap anggota kelompok yang bermasalah tadi (Zuraidah, 1999) justeru, program kaunseling kelompok tadi sudah tentu dapat menerapkan dan memupuk nilai nilai yang dirundung masalah tadi. Antara nilai nilai yang diterapkan dan memupuk nilai nilai positif sesama anggota yang dirundung masalah tadi. Antara nilai nilai yang diterapkan nilai oleh kaunselor dalam sesi kaunseling kelompok yaitu empati, simpati, belas kasihan, hormat menghormati dan sebagainya.

Ada setengah program yang dianjurkan oleh kaunselor disekolah meliputi kelompokkelompok ibadah perkhemahan peserta didik. Disini para peserta didik akan dihadapkan dengan kursus kursus yang bersesuian seperti kursus disiplin, kursus peningkatan akhlak dan sahsiah diri. motivasi diri, dan sebagainya. Disamping itu, mereka diberikan aktivitas dan program yang berbentuk ibadah. program ibadah ini dibagi dua yaitu aktivitas melibatkan ketahanan fizikal dan aktivitas melibatkan ibadah. program seperti perkhemahan, tracking dan menempuh halangan seperti sungai, mendaki bukit, masuk hutan dan sebagainya merupakan aktivitas aktivitas lasak yang diadakan untuk menguji ketahanan remaja dari segi fizikal, mental dan emosi mereka. manakala akitivitas ibadah pula peserta diminta berzikir, mengahafal surah surah populer, disamping dalam melaksanakan sholat, qiamulail dan sebagainya merupakan aktivitas-aktivitas yang dapat mengisi kerohanian dalam diri peserta didik. ketua komando dan fasiliator akan meminta remaja supaya mempunyai disiplin dalam pengurusan diri khusunya dalam penjagaan sholat sepanjang program itu. selesai sahaja kem ibadah yang pendek itu, adalah diharapkan remaja dapat membawa sedikit pengisian khususnya melibatkan aspek aspek kemantapan iman dan taqarub kepada Allah S.W.T (bermula mendekatkan diri kepada Allah S.W.T).

Penulis percaya program dan aktiviti seperti ini bukan sahaja dapat menyihatkan badan sahaja, melahirkan remaja yang cergas dan cerdas dari segi mentalnya, tetapi yang lebih penting dapat menerapkan nilai nilai bertanggung jawab, yakni diri, amanah dan boleh menyelesaikan masalah sendiri dalam keadaan genting. contohnya, aktiviti mendaki bukit misalnya bukan sahaja dapat melahirkan pelajar yang cerdas dari segi feizikalnya, bahkan dapat mewujudkan pelajar yang bertanggung jawab dalam memekul amanah karena telah diterapkan nilai bahawa anak anak buah (ahli ahli perkhemahan) perlu taat kepada perintah ketua ekspedisi pendakian. jika tidak, sudah tentu ada dikalangan anak anak buah dalam kumpulan sukar dikawal dan akan mendapat kemalangan semasa aktiviti.

Penulis juga memendang bahawa aktiviti ibadah seperti berzikir. qiamullail, menghafal surah surah lazin, disiplin dalam mengerjakan sholat dan sebagainya merupakan aktiviti yang secra tidak langsung dapat menerapkan nilai nilai positif yang sekaligus meningkatkan insane dalam diri seseorang. misalnya, aktivitas qiamullail dapat membentuk seseorang remaja itu supaya disiplin terhadap waktu, melatih kesadaran sendiri, latihan mengawal emosi dan melahirkan rasa taubat dalam diri. ini karena seseorang remaja itu diarahkan mengerjakan sholat qiamul secara berjamaah dengan tujuan untuk mendapatkan keredaan rasa bertobat dalam diri remaja.

Aktivitas masuk hutan dan perkemahan dalam hutan ini juga sekaligus memupuk sifat sifat prihatin, kepekaan dan budaya menyangi alam sekitar dari pada kegiatan pencemaran. Konselor perlu menemani dan senantiasa mengingatkan remaja supaya mengamalkan nilai nilai menjaga dan mengutamakan keberrsihan semasa di dalam hutan. Yang penting ialah 
remaja supaya dapat bertafakur melalui panca indra yang ada supaya senantiasa berfikir, memahami dan merenungkan alam semesta ciptaan ALLAH. S.W.T. rahasia rahasia kejadian Allah SWT.dan tujuan ciptaan Allah SWT.yang maha kuasa itu (As- Syeihkh ahmad, 2000) ini jelas dari ayat berikut yang bermaksud: "Sesungguhnya tentang kejadian langit dan bumi dan perselisihan malam dan siang, ada beberapa bukti bagi orang orang yang mempunyai fikiran. mereka yang mengingat Allah sambil berdiri, duduk dan berbaring dan memikirkan tentang kejadian langit dan bumi”. Remaja yang bertafakur ini sudah tentu wujud suatu kesadaran dalam diri, meningkatkan keimanan, mewujudkan penciptaan sebagai insan yang kerdil dimuka bumi ini dan dihrapkan mempunyai hikmah dalam diri supaya dapat memandu diri kearah insan yang saleh dan saleha dimuka bumi ini (Abdul Aziz, 2001).

Secara keseluruhannya, program perkhemahan ini dapat memantapkan lagi daya mental dan fizikal remaja dan di samping secara tidak langsung mereka diterapkan dengan nilai nilai luhur dalam diri seperti disiplin, kesabaran menempuh rintangan, tolong menolong, kerjasama, taat dengan perintah ketua dan yang paling penting ialah bersyukur dengan mewujudkan diri sebagai makhluk ciptaan Allah S.WT. dan dapat menikmati keindahan alam semesta ciptaan Allah S.W.T itu.

\section{Simpulan dan Saran}

Menjelang tahun 2020, adalah menjadiharapan kita semua supaya negaraa akan menjadi maju dari segi politik, sosial, ekonomi. yang lebih penting adalah kemajuan dari segi pembangunan Fizik negara ini adalah seiring dengan pembangunan dan kemantapan dari segi kejiwaan dan psikologi masyarakat (Nik, 1994). sebagaimana suatu dari satu tantangan dalam tahun 2020, yakni menekankan pentingnya nilai moral dan etika yan g kukuh bagi masyarakat demokratis, liberal, bertolak ansur, menyayangi adil dan sebagainya (Nordin, 1994). Tantangan-tantagan yang dikemukakan ini sesuai untuk golongan remaja ini kerena pada tahun 2020 mereka berada pada peringkat umur paing pruduktif (Ibrahim, 2001). Justeru, penulis merancanakan satu wadah terpadu sebagaimana yang telah dijelaskan ini dapat dipraktekkan oleh konselor dibantu oleh guru guru sekolah dengan sokongan orang tua supaya setiap permasalahan yang dihadapi oleh golongan remaja ini dapat dihadapi dengan bijaksana. Sebagaimana penelitian Nur lida yang menyatakan konselor orang propesional dan perlu menghayati nilai nilai murni berdasarkan akidah dalam kehidupannya sebagai kaunselor muslim, sifat sifat konselor islam perlu merujuk kepada sifat sifat kenabian Rasulullah S.A.W. yang merupakan model seorang konselor yang amat profesinal karena mendapat hidayah dari pada Allah S.W.T: adalah diharapkan konselor muslim dan bukan muslim dapat menjadikan Rasulullah SAW menajadi model konselor sepanjang zaman.

\section{Daftar Pustaka}

Abdul Aziz, M. Z. (2001). Metodologi Dakwah. Kuala Lumpur: Penerbit Universiti Malaya.

Agensi Dadah kebangsaan.2001. kenali dan perangi dadah. kementrian dalam negeri. kuala lumpur.

Ali yacob.1995. perkhidmatan kaunseling kes ditanah suci. kajang. Selangor. Makruf pub.

Amer Shakir zainolo.2001. membina kendiri unggul berkarisma. kuala lumpur.jelattek.

Aminah Hashim dan Arthur p. lioyd.1994. bimbingan dan kaunseling dimalaysia. kuala lumpur. dewan bahasa dan pustaka.

As Syaik Ahmad Ridha Hasbullah.200.taqurrub. mendekatkan diri kepada Allah S.W.T. kula lumpur. hidayah. 
Aziri Aziz.1995. teknik ingatan untuk pelajar. siri pelajar cemerlang. Quantum Leaning Publishers.

Fadhilah Abdul Alim \& Muhamad Abdul Shahbudin.1999.asas asas pembentukan akhlak mulia. kempas.johor. jahebarsa.

Mohd Sofian Aomar.aminuddin Yosof \& Borhan Yusof.2001. korikulum peranan dan implikasi. kuala lumpur.utusan.

Norlida Md Top .1999.persepsi pelajar tingkat 5 yang mengikutib aliran teknik disekolah menengah teknit batu pahat terhadap penghayatan nilai murni dirinya dan kaunselor. Tesis sarjana pendidikan dan bimbingan kaunseling fakulti pendidikan. UTM,johor.

Zuriadah Abdul Rahman.2001. pengenalan kaunseling kelompok.kuala lumpur. Utusan pub.

Abdul Ghafar, T. (1998). Strategi dan Kawalan Disekolah Sekolah. Kuala Lumpur: Dadah.

Abdullah, M. M. (2001). Kaunseling, Teori, Proses dan Kaedah. Edisi Kedua. . Selangor: Fajar Bakti.

Ghayani, S. M. (1996). Bimbingan Membina Minda dan Jiwa Remaja Cemerlang. Selangor: Pustaka Ilmi.

Habibah, A., \& Noran, F. (2002). Psikologi Personality. Kuala Lumpur: Dewan Bahasa dan Pustaka.

Ibrahim, M. (2001). Memimpin Remaja Sekolah. Kuala Lumpur: Dewan Bahasa dan Pustaka.

Ikhwan, Y. (2002). Kaunseling Kerir Menurut Perspektif Islam. Johor. Retrieved from Kertas kerja bimbingan dan kaunseling. April 2002. Fakulti pendidikan UTM. Skudai,: johor.sss

Ismail, A. A. (1998). Membina Minda dan Pribadi islam. Kuala Lumpur: Al-hidayah.

Johari, A. (1994). Nilai Nilai Islam 5 Membina Pribadi. Kuala Lumpur: Dewan Bahasa dan Pustaka.

Malaysia, K. p. (2002, Mei 1). Tugas dan Tanggung Jawab Kaunselor. Retrieved from http://members.tripodasia.com.mv/skkamill/bk.html

Nik, N. A. (1994). Penghayatan Wawasan Pembangunan Negara. Kuala Lumpur: Dewan Bahasa dan Pustaka.

Noordin, T. A. (1992). Pendidikan dan Wawasan 2020. Kuala Lumpur: Dewan Bahasa dan Pustaka.

Noordin, T. A. (1993). Perspektif Falsafah dan Pendidikan Di Malaysia. Kuala Lumpur: Dewan Kuala Lumpur Bahasa dan Pustaka.

Nordin, A. B. (1994). Reformasi Pendidikan Dalam Menghadapi Cabaran 2020. Kuala Lumpur: Nurin Enterprize.

Rogers, C. (1961). On a Person. Boston: Huoghtaon Mifflin Company.

Zahid, M. N. (2004). Wawasan Pendidikan Agenda Pengisian. Kuala Lumpur: Nurin Ent. 